\title{
Preface to the 1999 Edition
}

When I began the thinking that led to this book, Marxism was a lively topic within social and cultural anthropology. In the preface to the first edition that follows, I noted the connection between my work and the academic and political ferment that began in North America in the late $1960 s$. Thirty years later, the spirit of our times is decidedly different. After the collapse of the Soviet Union, many have consigned the writings of Marx to the dustbin of history, and to many, capitalism now appears as the only possible way to organize modern life.

So why return to Marx? My answer is that Marx's analysis of capitalism - as opposed to his more weakly developed notions about socialism continues to furnish an indispensable beginning point for understanding our times. All about us, we see an extension of the dynamics that Marx identified and explained: continuing commodification, technological innovation, ensuing competition among capitalists, the increasingly rapid movement of capital across the globe, with continuing crises, booms and busts. Perhaps the most macabre illustration of these processes is the recently uncovered black-market transfer of human body parts from executed prisoners in the People's Republic of China to high-tech medical laboratories of the United States. Decentralizing and fragmenting the production process, blurring old boundaries between nature and culture, these developments have been identified by some as "postmodern." 1

Whether or not capitalism has recently undergone a significant transition, the strength of the boom during the 1990s has begun to outpace that of the 1950 and 6os. And the "good times" generated are apparently not conducive to critical social analysis. But if Marx is any guide, expansion will not continue indefinitely, nor will it spread uniformly across social space. Recently, as I was commenting on the lack of any significant engagement with Marx in recent anthropological discussions, an elder in the field quietly asserted, "Wait until the next stock market crash."

Recent successes of world capitalism (ironically) constitute one reason, then, that Marx seems irrelevant to many today. But the collapse and all-

\footnotetext{
${ }^{1}$ David Harvey, The Condition of Postmodernity (Oxford: Basil Blackwell, 1989) and Fredric Jameson, "Postmodernism, or the Cultural Logic of Late Capitalism," New Left Review 146 (1984): 53-92.
} 
too-evident failures of socialist systems is another. Katherine Verdery recently began a book on this transformation with an epigraph: " $Q$ : What is the definition of socialism? A: The longest and most painful route from capitalism to capitalism."2

Marx's writings, in fact, furnish only the haziest outlines of what postcapitalism should be or how it should be brought about. It fell to others principally Lenin - to create actually-existing socialism. At the end of our century, it is clear - to me at least - that Lenin's project is dead, having resulted in tragedy for millions upon millions. But if Leninism must be distinguished from Marxism, some elements of Marx's own thought preconditioned these failures - none more so than his grand narrative of world history, the (teleological) notion that communism has to follow capitalism.

In a new book being published as a companion to this one, I examine the intersection between Marxism and what might be called modernism. Marxist Modern: An Ethnographic History of the Ethiopian Revolution analyzes this intersection in the particular case of Ethiopia, focusing on what Ethiopians understood Marxism-Leninism to be and the consequences of these understandings for the creation of a revolutionary state. What I seek to present here is precisely a marxism freed from the modernist teleologies that so attracted Ethiopian revolutionaries - in Stuart Hall's phrase, a "marxism without guarantees." 3

I have claimed that Marx's work continues to be relevant primarily as a model of capitalism. But capitalism is not my subject in this book, at least not directly. What I seek to do here is to transfer Marx's basic approach, in a way that he and others have not, to the analysis of a noncapitalist way of producing - namely to the Maale economy of southern Ethiopia where I have spent a number of years doing field research. In other words, I seek to apply Marx's method to a very different cultural-economic system. In doing so, I confront two vexing issues: (I) the relationship between socalled base and superstructure, and (2) the difference between structural and historical explanation.

The first issue has given rise to a large and contentious literature. Does the base determine the superstructure? Does it do so only in capitalism, or in noncapitalist modes of production as well? What are bases and superstructures in the first place? And, not least, what is determination? Marshall Sahlins, who has been one of the most persistent anthropologi-

${ }^{2}$ Katherine Verdery, What was Socialism, and What Comes Next? (Princeton: Princeton University Press, 1996).

${ }^{3}$ Stuart Hall, "The Problem of Ideology: Marxism without Guarantees," in David Morley and Kuan-Hsing Chen, eds., Critical Dialogues in Cultural Studies (London: Routledge, 1996), pp. 25-46. 
cal critics of the imposition of capitalist analytical categories upon other societies, has argued that Marxism itself is such an imposition, another species of "practical reason." 4 That particular (Marxist) analyses have fallen into this trap I have no doubt. What I have offered in this book is, however, a method of cultural analysis that escapes Sahlins's strictures. In the conclusion I contend:

ideology is not something that simply legitimates power. ... Rather it provides the very terms in which power regularly becomes power.... Once one starts with the realization that all empirical analysis must be carried out in particular superstructural terms, then the goal is not somehow to escape those terms in order to get down to the really real, the hard "economic" facts. Just the opposite: The task becomes one of interpreting and, in fact, deconstructing the cultural categories that are implicated in the continuance of productive inequalities wherever they can be found (p. 196).

This understanding of base and superstructure - a modification of G. A. Cohen's exposition hammered out in the course of an analysis of the Maale - suggests certain revisions to the way in which capitalism itself has been viewed. ${ }^{5}$ For Marx and many others, class within capitalism constitutes a primary (economic) reality, to which other forms of inequality are necessarily secondary. Recently, Judith Butler has argued that this view is manifestly inadequate, since social movements based on gender and sexuality cannot be understood as "merely cultural." 6 This book offers an extended argument for Butler's position. In this way, the analysis of a radically different political economy, that of the Maale, is helpful in modifying and extending Marx's own analysis of capitalism.

The second major issue that I confront concerns the relationship between structural and historical modes of explanation. Over the past three decades, structural models have lost all power to convince within anthropology. Nearly all anthropologists are now convinced that the locales they study are so caught up in change that pure "structure" no longer makes much sense. Consequently, structural forms of analysis have tended to be rejected as products of a colonial ideology, a static vision of the Other from which postcolonial theory will liberate us. In their place, "history" has become a touchstone, even a fetish, for virtually every school of current social and cultural anthropology.

My own view is somewhat different. I have argued that Marx's Capital

${ }^{4}$ Marshall Sahlins, Culture and Practical Reason (Chicago: University of Chicago Press, 1976).

${ }^{5} \mathrm{G}$. A. Cohen, Karl Marx's Theory of History: A Defence (Oxford: Clarendon Press, 1978).

6Judith Butler, "Merely Cultural," New Left Review 227 (1998): 33-44. 
is not a historical analysis, and yet it retains the power to inform analyses of change. It does this not by "predicting" exactly what will happen but by ordering a series of possibilities around a set of central, unstable contradictions. I see this form of structural explanation as one moment in a necessarily complex methodology, one that prepares the way for actual historical explanation. What I argue for, therefore, is not a rejection but a motivated transition from structural analyses (which are understood as heuristic and therefore incomplete) to fully historical analyses (which are seen as conditioned).

This transition is not easily accomplished. Gramsci described the stakes inherent in delimiting structural and historical explanations many years ago:

A common error in historico-political analysis consists in an inability to find the correct relation between what is organic and what is conjunctural. This leads to presenting causes as immediately operative which in fact only operate indirectly, or to asserting that the immediate causes are the only effective ones.... In the first case there is an overestimation of mechanical causes, in the second an exaggeration of the voluntarist and individual element. ${ }^{7}$

In order to realize its goal, historical anthropology must confront the complexity that Gramsci highlighted. Rather than attempting to generalize about the transition from structure to history (which may, in any case, be a dubious undertaking), I seek to illustrate it with a particular analysis of the Maale.

I have not revised this text, except to eliminate errors. In it I attempt to follow out the logic of a marxist approach across radically different cultural economies. At times, this leads me to disagree with Marx himself, and at other times it requires me to rely upon the work of non-marxist writers. My hope is that this book will provide a contemporary introduction to a classic mode of analysis in the human sciences, one that may go in and out of fashion but that is not likely to be superseded as long as we continue to live in a capitalist world order.

${ }^{7}$ Antonio Gramsci, Selections from the Prison Notebooks, edited and translated by Quintin Hoare and Geoffrey Nowell Smith (New York: International Publishers [1948-51], 1971), p. 178. Quoted in the conclusion to this volume, p. 212. 
A Klee painting named "Angelus Novus" shows an angel looking as though he is about to move away from something he is fixedly contemplating. His eyes are staring, his mouth is open, his wings are spread. This is how one pictures the angel of history. His face is turned toward the past. Where we perceive a chain of events, he sees one single catastrophe which keeps piling wreckage upon wreckage and hurls it in front of his feet. The angel would like to stay, awaken the dead, and make whole what has been smashed. But a storm is blowing from Paradise; it has got caught in his wings with such violence that the angel can no longer close them. This storm irresistibly propels him into the future to which his back is turned, while the pile of debris before him grows skyward. This storm is what we call progress.

Walter Benjamin, Theses on the Philosophy of History 
